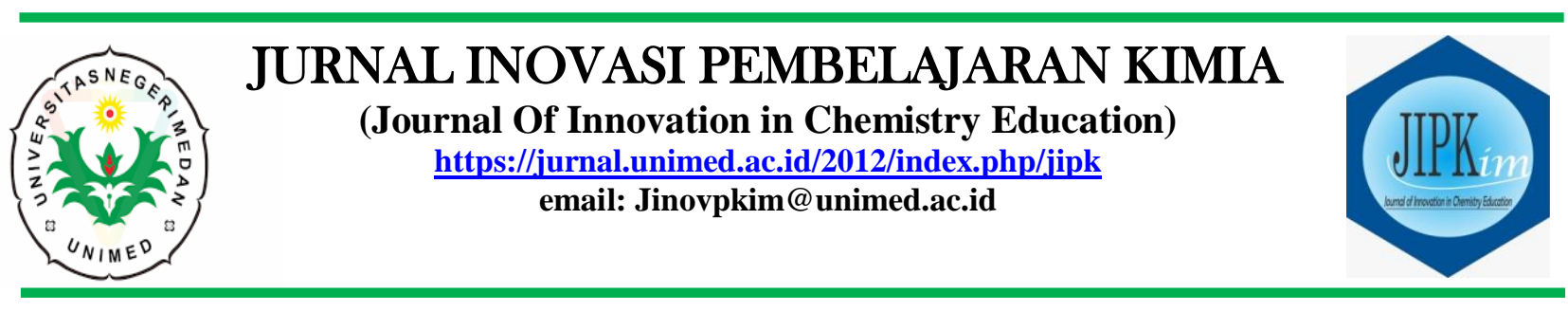

$\begin{array}{ll}\text { Masuk } & : \text { 21 Januari } 2021 \\ \text { Revisi } & : \text { 20 September } 2021 \\ \text { Diterima } & : 28 \text { Oktober } 2021 \\ \text { Diterbitkan } & : \text { 31 Oktober } 2021 \\ \text { Halaman } & : \text { 176 - 182 }\end{array}$

\title{
Pengaruh Penggunaan Media Webblog Berbasis HOTS Terhadap Motivasi dan Hasil Belajar Pada Materi Laju Reaksi
}

\author{
Bernika Evelyn Sibarani ${ }^{1 *}$, Marham Sitorus ${ }^{1}$ \\ ${ }^{1}$ Program Studi Pendidikan Kimia, Universitas Negeri Medan, Medan \\ *AlamatKorespondensi: bernikasibarani11@gmail.com
}

\begin{abstract}
This reseach goals to determine how the effect of knowing the effect of using Webblog media on the HOTS Evaluation Based Problem Based Learning Model on Motivation and Student Learning Outcomes in the Material of Reaction Rate. The sampling technique used is by using a purposive technique where class XI IPA 4 as an experimental class is taught using Webblog Media in the Problem Based Learning model using and XI IPA 5 as a control class that is taught using Power Point Media in the Problem Based Learning learning model based on HOTS evaluation. The analysis technique used is the mean difference test, the percent increase in learning outcomes, normality test, homogeneity test and hypothesis testing. The results obtained by the average value of the experimental and control classes in the pretest data were 36.25 and 27.25. The post-test scores for the experimental and control classes were 79 and 65.5. The correlation test for the effect of using Webblog media in the Problem Based Learning model on student motivation and learning outcomes is the value of rxy $=0.754$ which means there is a positive correlation between motivation and student learning outcomes.
\end{abstract}

Keywords: Webblog Media, Problem Based Learning Model, HOTS Questions

\section{PENDAHULUAN}

Pendidikan adalah sebuah proses dinamis dan berkelanjutan yang bertugas memenuhi kebutuhan siswa dan guru sesuai dengan minat mereka masing masing yang sangat penting bagi manusia. Pendidikan memiliki tanggung jawab untuk meningkatkan minat siswa, memperluas dan mengembangkan keilmuan mereka, dan membantu mereka agar mampu menjawab tantangan dan gagasan baru dimasa mendatang. Pendidikan harus mendesain pembelajaran dan yang responsive dan berpusat pada siswa agar minat dan aktivitas sosial mereka terus meningkat (Fadliana et al., 2013).

Mengingat ketersedian internet, guru sekarang memiliki peluang lebih besar untuk mengakses ke berbagai alat pendidikan yang dapat digunakan untuk meningatkan praktik pembelajaran yang berpusat pada siswa SMA dikels dan untuk terlibat dalam banyak interaksi dengan siswa SMA. Kesiapan materi online mulai dari video, slide, game, perangkat lunak interaktif dan banyak lagi ditemukan untuk 
membantu guru dalam melakukan pengajaran dan pembelajaran mereka (Keengwe et al., 2009). Para guru harus menerima bahwa dengan perkembangan media sosial dan teknologi pendidikan, pengetahuan konten dapat dihasilkan dan diseberluaskan lebih cepat dan luas daripada sebelumnya (June et al., 2014).

Webblog adalah bentuk aplikasi web yang menyerupai tulisan-tulisan (yang dimuat sebagai posting) pada sebuah halaman web umum. Weblog dapat dirangkum sebagai kumpulan website pribadi yang memungkinkan para pembuatnya menampilkan berbagai jenis isi pada web dengan mudah, seperti karya tulis, kumpulan link internet, dokumen- dokumen (file - file Word, PDF, dll), gambar ataupun multimedia. Webblog memiliki fasilitas interaksi dengan para pengunjungnya, seperti menggunakan buku tamu dan kolom komentar yang dapat memperkenankan para pengunjungnya untuk meninggalkan komentar atas isi dari tulisan yang dipublikasikan.

Pada tahun 2018, Kemendikbud mulai memberlakukan soal yang membutuhkan kemampuan berpikir tingkat tinggi atau "High Order Thinking Skill" atau HOTS pada ujian nasional (UN) dan pada Ujian Tulis Berbasis Komputer (UTBK). Sistem HOTS akan terus digunakan karena bertujuan untuk mengembangkan daya nalar siswa. Keputusan tersebut mendapat banyak keluhan dari para siswa mengenai sulitnya soal-soal yang ada.Menurutnya, penggunaaan HOTS dalam soal UN dan UTBK diterapkan untuk mendorong kemampuan berpikir kritis siswa (Kemendikbud, 2018).

Salah satu muatan dalam Kurikulum 2013 yaitu menuntut peserta didik mampu berpikir tingkat tinggi.Kemampuan berpikir tingkat tinggi / Higher Order Thinking Skills (HOTS) termasuk elemen kunci Kurikulum 2013. HOTS dapat dikembangkan dengan memaksimalkan kesiapan penerapan Kurikulum 2013. Kesiapan tersebut terlihat pada fokus Kurikulum 2013 yang cermin pada setiap tahapan kegiatan $5 \mathrm{M}$ yaitu menanya, mengamati, mengasosiasi, dan mengkomunikasikan

(Kristiantari, 2014).

\section{KAJIAN LITERATUR}

\section{A. Defenisi Belajar}

Belajar adalah suatu proses yang kompleks yang terjadi pada semua orang dan berlangsung seumur hidup, sejak dia masih bayi hingga keliang lahat nantinya. Proses pembelajaran merupakan suatu sistem. Dengan demikian, pencapaian standar proses untuk meningkatkan kualitas pendidikan dapat dimulai dari menganalisis setiap komponen yang dapat membentuk dan memengaruhi kualitas pendidikan, namun demikian tidak mungkin upaya meningkatkan kualitas dilakukan dengan memperbaiki setiap komponen yang serempak. Hal ini selain komponen - komponen itu keberadaannya terpacar, juga kita sulit menentukan kadar keterpengaruhan setiap komponen. Salah satu pertanda bahwa seseorang telah belajar adalah adanya perubahan tingkah laku dalam dirinya. Perubahan tingkah laku tersebut menyangkut baik perubahan yang bersifat pengetahuan (kognitif) dan keterampilan (psikomotor) maupun yang menyangkut nilai dan sikap. (Sadiman, 2009).

\section{B. Hasil Belajar}

Hasil belajar merupakan bagian terpenting dalam pembelajaran. Hasil belajar siswa pada hakekatnya adalah perubahan tingkah laku sebagai hasil belajar dalam pengertian yang lebih luas mencakup bidang kognitif, afektif dan psikomotorik (Sudjana, 2009). Menurut Slameto (2010) hasil belajar adalah kemampuan yang diperoleh anak setelah melalui kegiatan belajar.

Untuk memperoleh hasil belajar dilakukan evaluasi atau penelitian yang merupakan tindak lanjut atau cara untuk mengukur tingkat penguasaan siswa. Kemajuan prestasi belajar siswa tidak saja diukur dari tingkat penguasaan ilmu pengetahuan tetapi juga sikap dan 
keterampilan. Dengan demikian penilaian hasil belajar siswa mencakup segala hal yang dipelajari di sekolah, baik itu menyangkut pengetahuan, sikap dan keterampilan (Jihad \& Haris, 2013).

\section{Motivasi Belajar}

Beberapa pakar mengemukakan pandangannya tentang motivasi yang kemudian menghasilkan berbagai teori motivasi. Satu diantaranya yaitu teori motivasi yang dikemukakan oleh Abraham Maslow yang kemudian menjadi dasar dari teori motivasi. Dimana menurut Moslow motivasi adalah dorongan penyebab atribusi yang mengacu pada penyebab kejadian atau hasil menurut persepsi individu.

Fungsi motivasi menurut Sadirman yaitu (1) Mendorong manusia untuk berbuat. Motivasi dalam hal ini merupakan motor penggerak dari setiap kegiatan yang akan dikerjakan (2) Menentukan arah yang akan dicapai (3) Menyeleksi perbuatan, yakni menetukan perbuatan - perbuatan apa yang harus dikerjakan dengan menyisihkan perbuatan yang tidak bermanfaat bagi tujuan tersebut. Motivasi atau dorongan memiliki peran yang sangat kuat dalam menentukan terwujudnya suatu perbuatan (Khairani, 2013).

\section{Media Pembelajaran Webblog}

Webblog adalah bentuk aplikasi web yang menyerupai tulisan - tulisan (yang dimuat sebagai posting) pada sebuah halaman web umum. Webblog dapat dirangkum sebagai kumoulan website pribadi yang memungkinkan para pembuatnya menampilkan berbagai jenis isi pada web dengan mudah, seperti karya tulis, kumpulan link internet, dokumen - dokumen (file - file word, PDF, dll), gambar ataupun multimedia.

Untuk memiliki blog sangatlah mudah, murah bahkan gratis. Banyak blog - blog gratis yang disediakan internet, antara lain: wordpress.com, blogspot.com, weblog.com, multiply.com, co.id, dll. Untuk membuat dan mengelolanya - pun sangat mudah. Hanya dengan waktu 15 - 30 menit para calon blogger dipastikan memi blog dan dapat mengelolanya sesuai keinginan (Sutirman, 2013).

\section{E. Keterampilan Berpikir Tingkat Tinggi}

Keterampilan berpikir tingkat tinggi (higher order thinking skills) mencakup kemampuan berpikir kritis, logis, reflektif, metakognitif, dan kreatif. Keterampilan berpikir kritis diperlukan dalam menyelesaikan masalah dan membuat keputusan. Higher order thinking skills (HOTS) akan berkembang jika individu menghadapi masalah yang tidak dikenal, pertanyaan yang menantang, atau menghadapi ketidakpastian/ dilema. Menurut Lewis dan Smith (1993) berpikir tingkat tinggi akan terjadi jika seseorang memiliki informasi yang disimpan di dalam ingatan untuk memperoleh informasi baru, kemudian menghubungkan, dan/ atau menyusun dan mengembangkan informasi tersebut untuk mencapai suatu tujuan atau memperoleh jawaban/solusi yang mungkin untuk suatu situasi yang membingungkan.

HOTS juga disebut kemampuan berpikir strategis yang merupakan kemampuan menggunakan informasi untuk menyelesaikan masalah, menganalisa argumen, negosiasi isu, atau membuat prediksi (Underbakke et al., 1993). Keterampilan berpikir tingkat tinggi (HOTS) mencakup berpikir kritis, berpikir kreatif, problem solving, dan membuat keputusan (Lewis \& Smith, 1993).

\section{METODE}

Penelitian ini dilakukan di SMA NEGERI 1 BANDAR. Penelitian ini dilaksanakan pada bulan Oktober November Semester Ganjil Tahun Ajaran 2020/2021.

Populasi dalam penelitian ini adalah seluruh siswa kelas XI SMA Negeri 1 Bandar Tahun Ajaran 2020-2021 yang terdiri dari 5 Kelas IPA yang rata-rata siswa 30 siswa perkelas.

Pengambilan sampel dilakukan dengan cara purposif. Secara purposif di ambil sampel 2 kelas dengan kriteria buku 
panduan yang sama yaitu XI-IPA 4 dan XIIPA 5. Kelas XI-IPA 4 sebagai kelas eksperimen yang diberi pengajaran menggunakan Media Webblog pada model pembelajaran Problem Based Learningberbasis soal HOTS dan XI-IPA 5 sebagai kelas kontrol yang diberi pengajaran menggunakan Media Power Pointpada model pembelajaran problem based learningberbasis soal HOTS di SMA Negeri 1 Bandar.

Instrument tes yang digunakan dalam penelitian ini adalah tes hasil belajar kimia siswa yakni pretest dan post-test. Pretest diberikan kepada sampel sebelum perlakuan (treatment) dengan tujuan untuk mengetahui homogenitas dan kenormalan ataupun kesamaan karakteristik kemampuan awal siswa. Post-test diberikan setelah selesai proses perlakuan (treatment) dengan tujuan untuk mengetahui hasil belajar siswa.

Rancangan Penelitian

Keterangan:

T1 : Pretest

T2 : Post tes

X : Pengajaran menggunakan Media Webblog pada model pembelajaran problem Based learning berbasis evaluasi HOTS

Y : Pengajaran menggunakan Media Power Point pada model pengajaran Problem Based Learning dengan berbasis evaluasi HOTS

Tabel 1 Rancangan Penelitian

\begin{tabular}{lccc}
\hline \multicolumn{1}{c}{ Sampel } & Pre-Test & Perlakuan & Post-Test \\
\hline $\begin{array}{l}\text { Kelas } \\
\text { Eksperimen }\end{array}$ & $\mathrm{T}_{1}$ & $\mathrm{X}$ & $\mathrm{T}_{1}$ \\
$\begin{array}{l}\text { Kelas } \\
\text { Kontrol }\end{array}$ & $\mathrm{T}_{2}$ & $\mathrm{Y}$ & $\mathrm{T}_{2}$ \\
\hline
\end{tabular}

Dalam penelitian ini data yang di olah adalah hasil belajar siswa kedua kelas. Teknik analisis data yang digunakan adalah analisis dengan menggunakan rumus uji - $\mathrm{t}$ pihak kanan.

\section{HASIL DAN PEMBAHASAN}

Data yang diperoleh dalam penelitian ini meliputi nilai pre-test, nilai post-test dan hasil motivasi belajar siswa. Nilai pre-test yang digunakan untuk melihat pengetahuan awal siswa mengenai materi Laju Reaksi pada kedua kelas penelitian sebelum diberikan perlakuan dengan model pembelajaran yang sama tetapi media yang digunakan berbeda, nilai post-test atas hasil belajar pada kedua kelas setelah diberikan perlakuan dengan model pembelajaran yang sama tetapi media yang digunakan berbeda, dan hasil motivasi belajar siswa untuk mengetahui apakah ada pengaruh motivasi terhadap hasil belajar siswa.

Tabel 2 Data Pretest Siswa

\begin{tabular}{lcc}
\hline & Eksperimen & Kontrol \\
\hline Nilai Minimum & 10 & 5 \\
Nilai Maksimum & 80 & 70 \\
Nilai Rata - Rata & 36.25 & 27.25 \\
Standart Deviasi & 2.65 & 2.34 \\
Varians & 133.72 & 102.53 \\
\hline
\end{tabular}

Berdasarkan tabel maka dapat digambarkan perbedaan hasil perolehan ratarata nilai pri-test kelas eksperimen dan kelas kontrol.

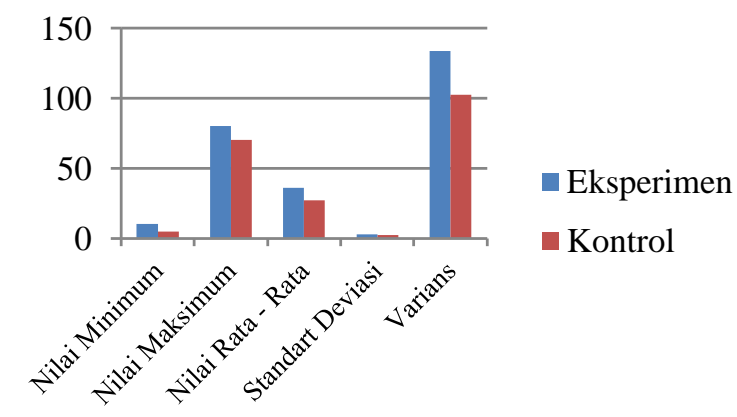

Gambar 1 Data Pretest Siswa

Tabel 3 Data Postest Siswa

\begin{tabular}{lcc}
\hline & Eksperimen & Kontrol \\
\hline Nilai Minimum & 65 & 40 \\
Nilai Maksimum & 90 & 80 \\
Nilai Rata - Rata & 79 & 65.5 \\
Standart Deviasi & 3.01 & 2.52 \\
Varians & 173.2 & 120.78 \\
\hline
\end{tabular}

Berdasarkan tabel maka dapat digambarkan perbedaan hasil perolehan rata- 
rata nilai post-test kelas eksperimen dan kelas kontrol

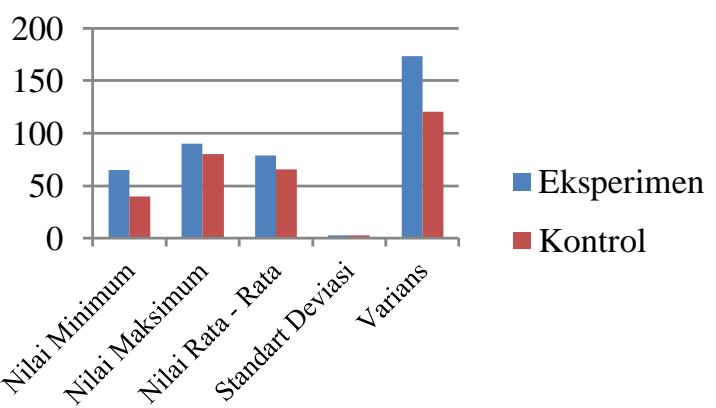

Gambar 2 Data Postest Siswa

Uji normalitas dilakukan dengan menggunakan uji Chi-kuadrat pada taraf signifikansi $\alpha=0,05$. Hasil pengujian normalitas data pre-test dan post-test di kelas Eksperimen dan kelas Kontrol dapat dilihat pada tabel di bawah ini.

Tabel 4 Perhitungan Normalitas Data Penelitian

\begin{tabular}{lllll}
\hline Kelas & $\begin{array}{l}\mathrm{X}^{2} \text { Hitun } \\
\mathrm{g}\end{array}$ & $\begin{array}{l}\mathrm{X}^{2} \text { Tabe } \\
1\end{array}$ & $\alpha$ & Ket \\
& 6.75 & 11.07 & 0.0 & Norma \\
Eksperime & 6.75 & & 5 & 1 \\
\hline
\end{tabular}

Dari hasil perhitungan uji normalitas data penelitian di atas, maka dapat disimpulkan bahwa data penelitian dinyatakan normal, sehingga telah memenuhi syarat untuk dilakukan pengujian selanjutnya.

Uji homogenitas dilakukan dengan membandingkan nilai varians dari hasil belajar dan motivasi belajar siswa yang diperoleh dari kedua kelas. Ringkasan hasil pengujian homogenitas data hasil belajar dan motivasi belajar siswa dapat dilihat pada tabel di bawah ini.

Tabel 5 Pengujian Homogenitas Data Penelitian

\begin{tabular}{lcccc}
\hline \multicolumn{1}{c}{ Data } & $\begin{array}{c}\text { Varian } \\
\text { S }\end{array}$ & $\begin{array}{c}\mathbf{F}_{\text {hitun }} \\
\mathbf{g}\end{array}$ & $\begin{array}{c}\mathbf{F}_{\text {tabe }} \\
\mathbf{l}\end{array}$ & $\begin{array}{c}\text { Kesimpula } \\
\mathbf{n}\end{array}$ \\
\hline Hasil & 193.35 & 148 & 2.17 & Homogen \\
Belajar & 130.19 & & & \\
Motivas & 325.73 & 133 & 2.17 & Homogen \\
i Belajar & 244.53 & & &
\end{tabular}

Dari hasil pengujian uji homogenitas data penelitian di atas, maka dapat disimpulkan bahwa data penelitian $(\alpha=0,05)$ dinyatakan homogen sehingga telah memenuhi syarat untuk dilakukan pengujian hipotesis.
Setelah diketahui bahwa data berdistribusi normal dan homogen, maka dapat dilakukan uji hipotesis dengan menggunakan uji statistik yaitu uji t-kedua pihak. Pengujian dilakukan dengan taraf signifikan $\alpha=0,05$. Uji ini digunakan untuk mengetahui apakah hipotesis dalam penelitian ini ditolak atau diterima. Data hasil perhitungan uji hipotesis dapat dilihat pada tabel berikut ini.

Tabel 6 Uji Hipotesis Motivasi Siswa

\begin{tabular}{lcccccc}
\hline \multicolumn{1}{c}{ Kelas } & $\mathbf{X}$ & Varians & $\mathbf{T}_{\text {hitung }}$ & Ttabel & $\boldsymbol{\alpha}$ & Ket \\
\hline Eksperimen & 107.97 & 325.73 & \multirow{2}{*}{2.38} & \multirow{2}{*}{1.685} & \multirow{2}{*}{0.05} & $\begin{array}{c}\text { Ho } \\
\text { diterima }\end{array}$ \\
\hline
\end{tabular}

Dari hasil perhitungan data pada tabel di atas, diperoleh bahwa harga $\mathrm{t}$ pada $\alpha=0,05$ adalah $t_{\text {hitung }}=2.38$ sedangkan $t_{\text {tabel }}=1,685$. Dari hasil yang diperoleh tersebut yaitu $t_{\text {hitung }}$ $>t_{\text {tabel }}(2,38>1,685)$, maka $\mathrm{H}_{0}$ ditolak dan $\mathrm{Ha}$ diterima. Sehingga dapat disimpulkan bahwa Ada perbedaan antara motivasi belajar siswa yang diajarkan dengan media Webblog pada model Problem Based Learning berbasis evaluasi HOTS dengan aktivitas belajar siswa dengan media Power Point pada model Problem Based Learning berbasis evaluasi HOTS pada materi Laju Reaksi.

Tabel 7 Uji Hipotesis Hasil Belajar Siswa

\begin{tabular}{lcccccc}
\hline \multicolumn{1}{c}{ Kelas } & $\mathbf{X}$ & Varians & $\mathbf{T}_{\text {hitung }}$ & Ttabel & $\boldsymbol{\alpha}$ & Ket \\
\hline Eksperimen & 57.62 & 130.19 & 2.74 & \multirow{2}{*}{1.68} & \multirow{2}{*}{0.05} & $\begin{array}{c}\text { Ho } \\
\text { Kontrol }\end{array}$ \\
\hline
\end{tabular}

Dari hasil perhitungan data pada tabel di atas, diperoleh bahwa harga t pada $\alpha=0,05$ adalah thitung $=2,74$ sedangkan ttabel $=$ 1,685. Dari hasil yang diperoleh tersebut yaitu $\mathrm{t}_{\text {hitung }}>\mathrm{t}_{\text {tabel }}(2,74>1,685)$, maka $\mathrm{H}_{0}$ ditolak dan Ha diterima. Sehingga dapat disimpulkan bahwa ada perbedaan antara hasil belajar siswa yang diajarkan dengan media Webblog pada model Problem Based Learning berbasis evaluasi HOTS dengan hasil belajar siswa dengan media Power Point pada model Problem Based Learning berbasis evaluasi HOTS pada materi Laju Reaksi.

Untuk mengetahui hubungan motivasi belajar dengan peningkatan hasil belajar siswa, maka digunakan analisis uji korelasi 
product moment. Data hasil dapat dilihat pada tabel di bawah ini.

Tabel 8 Uji Korelasi

\begin{tabular}{lccccc}
\hline \multicolumn{1}{c}{ Data } & $\mathbf{N}$ & $\mathbf{r}_{\mathbf{x y}}$ & $\mathbf{r}_{\text {tabel }}$ & $\mathbf{C D}$ & Ket \\
\hline $\begin{array}{l}\text { Hasil } \\
\text { Belajar }\end{array}$ & & & & & \\
$\begin{array}{l}\text { dan } \\
\text { Motivasi }\end{array}$ & 20 & 0.754 & 0.444 & $56.2 \%$ & $\mathrm{Ha}_{\text {diterima }}$ \\
\begin{tabular}{l} 
Belajar \\
\hline
\end{tabular} & & & & & \\
\hline
\end{tabular}

Berdasarkan hasil pengolahan data dengan menggunakan rumus product moment, untuk korelasi antara motivasi dengan hasil belajar siswa pada kelas eksperimen diperoleh harga $\mathbf{r}_{\mathbf{x y}}>\mathbf{r}_{\text {tabel yakni }}$ 0,754 > 0,444, sehingga dapat disimpulkan bahwa ada korelasi positif antara motivasi dengan hasil belajar. Data lebih lengkap dapat dilihat pada

\section{DISKUSI}

Berdasarkan hasil analisis di dapat hasil belajar siswa sebesar 19,88\% dan keterampilan generik sains 43,2\% sedangkan pada penelitian ini didapat peningkatan hasil belajar sebesar 74,34\% dan motivasi belajar siswa diperoleh $11,67 \%$. Hal ini terjadi karena model pembelajaran ini menghubungkan pembelajaran dengan permasalahan yang terjadi di dalam kehidupan sehari-hari sehingga siswa lebih tertarik dalam mempelajari sesuatu yang berkaitan dengan kehidupan sehari-hari. Selain itu siswa juga sebagai pusat dalam pembelajaran, siswa bersama-sama dengan temannya memecahkan permasalahan yang diberikan guru dengan bantuan media pembelajaran Webblog. Hal ini juga dapat meningkatkan kerjasama antara siswa dan membangun relasi yang baik antra siswa maupun siswa dengan guru.

\section{KESIMPULAN}

Ada perbedaan motivasi belajar siswa yang dibelajarkan dengan menggunakann media Webblog pada model pembelajaran Problem Based Learning berbasis evaluasi HOTS dengan terhadap motivasi belajar siswa yang dibelajarkan menggunakan media Power Point pada model pembelajaran Problem Based Learning. Motivasi belajar siswa menggunakan media Webblog $(25,73)$ tidak sama dengan motivasi belajar siswa yang dibelajarkan dengan media Power Point pada model pembelajaran Problem Based Learning $(22,94)$.

Ada perbedaan hasil belajar siswa yang dibelajarkan dengan media Webblog pada model pembelajaran Problem Based Learning (PBL) berbasis evaluasi dengan hasil belajar siswa yang dibelajarkan menggunakan media Power Point pada model pembelajaran Problem Based Learning. Hasil belajar siswa dengan menggunakan model pembelajaran PBL dengan media kartu domino $(79,0)$ tidak sama dengan hasil belajar siswa menggunakan media Power Point pada model pembelajaran Problem Based Learning $(65,5)$.

Korelasi motivasi belajar dengan peningkatan hasil belajar siswa yang dibelajarkan dengan menggunakan media Webblog melalui model pembelajaran PBL termasuk kategori korelasi positif dengan nilai rhitung sebesar 0,754. Sehingga kontibusi aktivitas belajar siswa terhadap peningkatan hasil belajar adalah 56,2\%

\section{DAFTAR PUSTAKA}

Fadliana, H. N., Redjeki, T., \& Nurhayati, N. D. (2013). Studi Komparasi Penggunaan Metode PBL (Problem Based Learning) Dilengkapi dengan Macromedia Flash dan LKS (Lembar Kerja Siswa) Terhadap Prestasi Belajar Ditinjau dari Motivasi Belajar Siswa Materi Asam, Basa dan Garam Kelas VII SMP Negeri 1 Jaten Karangan. Jurnal Pendidikan Kimia (JPK), 2(3), 158-165. https://jurnal.fkip.uns.ac.id/index.php/ki mia/article/view/2638

Jihad \& Haris. (2013). Evaluasi Pembelajaran. Yogyakarta: Multi Pressindo.

June, S., Yaacob, A., \& Kheng, Y. K. (2014). 
Assessing the Use of YouTube Videos and Interactive Activities as a Critical Thinking Stimulator for Tertiary Students: An Action Research. International Education Studies, 7(8), 56-67.

https://doi.org/10.5539/ies.v7n8p56

Khairani, M., (2013), Psikologi Belajar, Aswaja Pressindo, Yogyakarta.

Keengwe, J., Onchwari, G., \& Onchwari, J. (2009). Technology and Student Learning: Toward a Learner- Centered Teaching Model. Association for the Advancement of Computing in Education Journal, 17(1), 11-22. https://www.learntechlib.org/p/26258/

Kemendikbud., (2018), Buku Penilaian Berorientasi Higher Order Thinking Skilss Program Peningkatan Kompetensi Pembelajaran Berbasis Zonasi, Kemendikbud, Jakarta.

Kristiantari, R. (2014). Analisis Kesiapan Guru Sekolah Dasar dalam Mengimplementasikan Pembelajaran Tematik Integratif Menyongsong Kurikulum 2013. JPI (Jurnal Pendidikan Indonesia), 3(2), 460-470. https://doi.org/10.23887/jpiundiksha.v3i2.4462

Lewis, A., \& Smith, D. (1993). Defining Higher Order Thinking. Theory Into Practice, 32(3), 131-137. https://doi.org/10.1080/0040584930954 3588

Sadiman, Arief S., dkk. (2009). Media Pendidikan, Pengertian, Pengembangan, dan Pemanfaatannya. Jakarta: Rajawali Press.

Slameto., (2010), Belajar Faktor-faktor yang Mempengaruhinya, Rineka Cipta, Jakarta.

Sudjana, Nana. (2009). Penilaian Hasil Proses Belajar Mengajar. Bandung: PT. Remaja Rosdakarya.
Sutirman, (2013), Media Dan Model - Model Pembelajaran Inovatif, PT. Graha Ilmu, Yogyakarta.

Underbakke, M., Borg, J. M., \& Peterson, D. (1993). Researching and Developing the Knowledge Base for Teaching Higher Order Thinking. Theory Into Practice, 32(3), 138-146. https://doi.org/10.1080/0040584930954 3589 